\title{
Granites and pegmatites of the collisional and intra-plate magmatism of the Baikal area: age, mineralogical and geochemical types and genesis peculiarities
}

\author{
Viktor Antipin $^{1 *}$, Nataliya Sheptyakova ${ }^{1}$, Larisa Kushch ${ }^{1}$, Valentina Makrygina ${ }^{1}$
}

\begin{abstract}
${ }^{1}$ Vinogradov Institute of Geochemistry, SB RAS, 664033 Irkutsk, Russia; antipin@igc.irk.ru (V.A.); gorlacheva@igc.irk.ru (N.Sh.); koush@igc.irk.ru (L.K.); vmakr@igc.irk.ru (V.M.) *Correspondence: antipin@igc.irk.ru; Tel.: +7-3952-42-70-56
\end{abstract}

\begin{abstract}
The paper presents new data on mineralogical-geochemical peculiarities of the granites and pegmatites of the Baikal area (Olkhon Region) with implications for the age, generation conditions and geodynamic settings of magmatism. The early Paleozoic granitoids of the Olkhon region are syncollisional formations produced from the gneiss-schistose substratum of the Olkhon metamorphic sequences. Pegmatoid granites and pegmatites of the Region were generated within a wide age range (458-390 Ma) and include different mineralogical and geochemical types. Amongst the Early Paleozoic granitoids, pegmatoid rocks are products of the collisional magmatism evolution and are similar to granites in terms of the mineral composition and distribution patterns of rare and rare earth elements. On the Olkhon island (Baikal lake) the pegmatite of the Tashkiney vein belong to the Be-Nb-Ta mineralogical-geochemical type demonstrating high contents of $\mathrm{W}, \mathrm{Sn} \mathrm{U}$, Th and very low concentrations of $\mathrm{Li}$ and volatile components (F, B). In the Pryolkhonye area, vein pegmatite Iliksin is with $\mathrm{Li}, \mathrm{Be}, \mathrm{Nb}, \mathrm{Ta}$ mineralization (lepidolite, vorobyevite, samarskite et al). The studied pegmatite veins are similar both by the profound negative $\mathrm{Ba}, \mathrm{Sr}, \mathrm{Eu}$, and $\mathrm{Zr}$ anomalies. The zircons from the Tashkiney vein $(390 \pm 5.0 \mathrm{Ma})$ and of the Iliksin vein $(430.1 \pm 2.2 \mathrm{Ma}, \mathrm{U}-\mathrm{Pb}$ isotope LA ICP MS metod) indicate the formation of pegmatite at the late post-collisional stage of magmatism in the Olkhon Region. As regard to mineralogical and geochemical characteristics, vein pegmatites with amazonite (Ainsky and Ulan-Nur) belong to the Li-F type. The tantalum mineralization, represented by microlites and minerals of the columbite-tantalite group is associated with the Ainsky amazonite pegmatite. As opposed to the Early Paleozoic syncollisional granitoids and pegmatoid formations, the middle Paleozoic vein bodies of pegmatites (Tashkiney, Iliksin, Ainsky, Ulan-Nur) are regarded as rare-metal pegmatites. In terms of geochemical characteristics, they are similar to the rare-metal pegmatoid granites and pegmatites of the intraplate setting widespread in Mongolia and Transbaikalia. The rare-metal mineralization in the Olkhon region may be genetically related to the evolution of Be-Nb-Ta and $\mathrm{Li}-\mathrm{F}$ types of the post-collisional granites and pegmatites.
\end{abstract}

Keywords: Paleozoic granitoids, pegmatites, age, collisional, mineralogical and geochemical types, mineralization, minerals, post-collisinal, intra-plate, magmatism, amazonite, genesis

\section{Introduction}

The most important feature of the Central Asian fold belt is the large-scale development of granitoid magmatism, which was intensively manifested in connection with Caledonian accretion-collision events and post-collision geological processes, which often culminate in pegmatoid formations in the southern frame of the Siberian craton [1-6]. According to U-Pb dating (SHRIMP-II, VSEGEI Institute, St. Petersburg), in Baikal area early Paleozoic granitoid magmatism, which is integrated into the Sharanur collision complex, demonstrated a wide age range (505-477 Ma) in Priolkhonye and on the Olkhon island, where it forms large massives: Sharanur, Tashkiney and Southern Olkhon. The complex of migmatites and granitogneisses is quite distinct in the structure of the Olkhon region in the form of dome zones among the Olkhon 
strata rocks with areas of intensively manifested migmatization and granitization (Figure 1). These formations are an autochthonous facies of granitoid magmatism; however, the most widespread here are intrusive bodies of biotite, less often amphibole-biotite, sometimes porphyritic granites, forming fairly large massifs, which are attributed to the main variety of granitoids of the Sharanur complex. Among them, there is a manifestation of small inter-strata bodies of medium-and fine-grained, sometimes pegmatoid leucogranites, or schlieric pegmatites, studied on the Olkhon island in the area of the Southern Olkhon massif.

The Caledonian magmatism of Pribaikalye (Khamar-Daban and Olkhon regions) is represented by granitoids qualified as S-type syncollisional rocks, which are close to the average composition of the continental crust. Dominant among them are granitoids of the calc-alkaline and subalkaline series, with gneisses and shales of the Khamar-Daban and Olkhon metamorphic strata acting as their melt source. This is proven by the inheritance of granitoid compositions from their host rocks, and dependence on the composition of the crustal protolith. Comparison of geochemical characteristics of early Paleozoic granitoid rocks in the southern frame of the Siberian craton with granitoids of modern and ancient collision zones (the Himalayas and Central Spain) confirmed similarity of their composition [9-11]. Along with pegmatoid leucogranites and pegmatites demonstrating genetic relation to the processes of formation and evolution of early Paleozoic magmatism, vein and isometric bodies of pegmatites with rare-metal mineralization were explored in the Olkhon region of Pribaikalye (Figure 1). These occurrences of later magmatism are usually controlled by the formation of submeridional fractures and take a secant position with respect to collisional structures within individual terrains of the Olkhon region. Their geological position and the first age data may indicate manifestation of magmatism of the new Hercynian stage within the intra-plate geodynamic environment in Pribaikalye. The present study is focused on the comparison of different age granites and pegmatites formed in diverse geodynamic environments in the Olkhon region; their mineralogical and geochemical typification is presented with the analysis of their origin sources based on new isotopic and geochemical data.

\section{Research methods}

The authors accomplished geological mapping of key zones of the development of various types of pegmatoid granitoids with representative selection of specimens and geochemical samples at the areas explored. The study was specifically focused on the detailed testing of rare-metal rocks of the Olkhon region, for which precision geochemical data were not yet available, and their comparison with the granitoids of the reference collisional Sharanur complex was performed. Silicate analyses were conducted according to the classical chemical method (analysts G.A. Pogudina, T.V. Ozhogina) and RFA (analyst A.L. Finkelstein) according to the standard method with an error of 0.5-5.0 \%; alkaline elements were determined by flame photometry with an error of 5-10 \% by L.V. Altukhova and I.M. Khmelevskaya; rare and rare earth elements (REE) were analyzed by ICP-MS $(\sigma \pm 5-10 \%)$ by L.A. Chuvashova and O.V. Zarubina with an error of 10-20\%. All analyses were accomplished in the Resource Sharing Center of ISC SB RAS using the equipment of the RSC of the Institute of Geochemistry SB RAS and certified standards [12].

At the Geological Institute, Ulan-Ude, Russia, U-Pb zircon dating by laser ablation and sector-field mass spectrometry with inductively coupled plasma LA-SF-ICP-MS method was applied using a Thermo Sscientific element XR single-collector SF ICP mass spectrometer. Measurements for standard zircons showed the error of dating less than $2 \%$. The result of LASF-ICP-MS dating of zircons from Paleozoic pegmatoids rocks of Olkhon region were analyzed by V.B. Khubanov [13].

\section{Geological structure, age, mineralogical and geochemical types of pegmatoid granites and pegmatites of Pribaikalye (Olkhon Region)}




\subsection{Leucogranites and pegmatites in the Sharanur collisional complex}

In addition to the domed zones (Sharanur dome and others) characteristic of Pribaikalye collision magmatism formed by the alternation of gneiss-granite and migmatite series of rocks, it is characterized by the formation of large intrusive massifs, in which pegmatoid leucogranites with biotite or pegmatites are sometimes manifested near contacts with the host metamorphic strata. This is a small interstratal body of medium - to fine-grained leucogranites, or schlieren of pegmatoid structure. Due to their spatial association with early Paleozoic magmatism, it is most likely that these rocks are a product of the magmatic evolution of larger intrusions of Sharanur granitoids. Their age was found to fall within a fairly narrow range (465-486 Ma) for the granites of the Sharanur complex [6] the granosienites and quartz syenites (495 $\pm 6 \mathrm{Ma}$ ) on the Olkhon island are considerably older [3] but the granites in the Central Dome Zone of Priolkhonye are somewhat younger $(458 \pm 2 \mathrm{Ma})$ [14]. The latter are similar in age to Olkhon veined pegmatoid granites intersecting them $(455 \pm 5 \mathrm{Ma}$, c. Shibetskiy) [15]. It is also established that the most common Sharanur biotite granites, and similar pegmatoid granites and leucogranites have petrographic similarity and are usually composed of albite-oligoclase, $\mathrm{K}-\mathrm{Na}$ feldspar, biotite and quartz, and accessory minerals in them are represented by garnet, apatite, zircon, titanite and allanite. Pegmatoid veins and schlieren-like formations are similar in petrochemical characteristics to the composition of fine-grained Sharanur leucogranites and fall under the category of normal alkalinity with a predominance of K over $\mathrm{Na}$ (Table 1, Figure 2). As late products of the evolution of the Sharanur complex, they are geochemically similar to them in terms of the nature of rare elements distribution spectra. As the spidergram and REE distribution diagram show, the average compositions of pegmatoid schlierens and pegmatites practically do not go beyond the areas characterizing geochemical features Pribaikalye Sharanur complex granites (Table 1,2; Figure 3).

\section{Rare metal pegmatites of various mineralogical and geochemical types}

\subsection{Pegmatite Tashkiney (the Olkhon island) with Be-Nb-Ta mineralization}

In the Olkhon region of Pribaikalye (the Olkhon island, the Tashkiney valley) among the migmatized gneisses of the Olkhon strata, a zonal branched vein with apophyses of coarsemedium-grained rare-metal pegmatoid granites was found for the first time [10]. The vein is of submeridional strike and is up to $280 \mathrm{~m}$ long, its thickness varying from the first meters to 20-30 $\mathrm{m}$ (Figure 4A). In the southern edge of the vein body, a schlier of coarse-grained pegmatite was identified with a transition to fine-block separations in the swells and with a mediumgrained structure in the endocontact zone. Along with feldspar and quartz, garnet grains in association with biotite, muscovite and crystals $(3-6 \mathrm{~cm})$ of beryl (aquamarine) are detected in the Tashkiney vein. There are also magnetite, titanite, and apatite. During mineralogical studies, the compositions of rare minerals were determined using Geol Superprobe-733 and JXA 8200 microanalyzers (analyzed by L.F. Suvorova): monazite, xenotime, euxenite, zircon, thortveitite, ittro-wolframite, Nb-Ta-wolframite, wolframoixiolite, cassiterite [17]. Pegmatoid microclinicalbite granites of Tashkiney with a large schlier separation of rare metal pegmatite are essentially potassium rocks $\left(\mathrm{K}_{2} \mathrm{O}=5.66-8.60\right.$ wt.\%) (Table 3, Figure 2$)$, in which the $\mathrm{K}_{2} \mathrm{O} / \mathrm{Na}_{2} \mathrm{O}$ ratio is 1.3-2.4. They have anomalous geochemical features and are strongly enriched with lithophilic and highly charged elements: $\mathrm{Be}, \mathrm{Cs}, \mathrm{Rb}, \mathrm{Ta}, \mathrm{Nb}, \mathrm{Sn}, \mathrm{W}, \mathrm{Y}$ when compared with the average composition of the upper continental crust. At the same time, deep minima of $\mathrm{Li}, \mathrm{Ba}, \mathrm{Sr}, \mathrm{Eu}$, and $\mathrm{Zr}$ concentrations are characteristic of pegmatite Tashkiney (Table 3, 4, Figure 3A).

The obtained geochemical characteristics undoubtedly distinguish the rare-metal pegmatoid formations of the Tashkiney from the typical Sharanur collisional granites of the Olkhon island, and they are characterized by the lowest, indicator for rare metal rocks, $\mathrm{Zr} / \mathrm{Hf}$ ratios: $(2.7-5.3), \mathrm{Nb} / \mathrm{Ta}(1.2-2.4)$ and $\mathrm{La} / \mathrm{Yb}(4.8-7.9)$. Pegmatoid granites have a 
characteristic distribution spectrum of rare earth elements with a convergence of light and heavy REE levels and differ from Sharanur granitoids by the presence of a deep Eu minimum (Figure 3B), which is characteristic of igneous rocks formed with significant participation of feldspar fractionation. They are classed as Be-Nb-Ta mineralogical-geochemical type with low contents of volatile components (F, B) and Li (Table 3 ).

Due to the established significant geochemical difference between the rare-metal pegmatite of the Tashkiney region and the rocks associated with the formation of the early Paleozoic Sharanur complex, U-Pb dating of zircons (SHRIMP-II) from the Tashkiney vein, was performed in the laboratory of isotope research (Geological Institute of the Kola Science Center, Apatity, analyst T.V. Bayanova) on single zircon grains. Isotopic U-Pb studies were performed on a seven-channel solid-phase mass spectrometer Finnigan MAT-262 (RPQ) in static mode with reproducibility errors along the axes assumed to be $0.5 \%$. Three zircon grains from the Tashkiney pegmatite showed concordant ages of $390 \pm 5 \mathrm{Ma}$, which are different from the Sharanur granitoids dates, and correspond to the Middle Devonian age.

\subsection{Iliksin pegmatite (Priolkhonye) with $\mathrm{Li}-\mathrm{Rb}-\mathrm{Be}-\mathrm{Nb}$-Ta mineralization}

Iliksin rare-metal pegmatite vein located among the Buguldey massive gabbroids in the Western part of Priolkhonye (Iliksin valley) is of considerable interest. The massive is situated in the rocks of the Anga suite along the Baikal lake and takes up an area of about $90 \mathrm{~km}^{2}$ (Figure 4B). The Anga suite is formed by metamorphic rocks dominated by garnet-biotite and biotite often migmatized gneisses with occurrences of carbonate rocks, quartzites and broken intrusions of the basic and diorite composition in the region.

The pegmatite vein extends in a submeridional direction for a distance of about 140-145 $\mathrm{m}$ and its thickness varies from $20 \mathrm{~m}$ in the north to almost $50 \mathrm{~m}$ in the southern part. The vein body was opened by a ditch, so the vein vertical section explored revealed a rather complex internal structure [18]. The southern more isometric part is represented by a graphic pegmatite, essentially feldspar with biotite and garnet, which is similar in mineral composition to other pegmatite veins of this area, lying among the Anga suite gneisses, and usually having a biotitequartz-feldspar composition. In this part of the Iliksin pegmatite body no rare-metal mineralization occurrences were found. In contrast to the southern occurrence, in the northern part pegmatite takes a more vein-like shape (Figure 4B) with protolithionite deposited in the rock instead of biotite. In the northernmost occurrence of the Iliksin vein body, in a small block zone with albite and $\mathrm{K}-\mathrm{Na}$ feldspar, the paragenesis of the following rare metal minerals was established: lepidolite, vorobyevite, polychrome tourmaline, rare minerals bismuth-tantalites and bismuth-columbites. Here, in the upper quartz-albite end of the vein, paragenesis of albite with fluorite is observed [18].

Judging by the composition and geochemical characteristics, two types of pegmatoid formations are clearly distinguished in the Iliksin pegmatite body (Table 3, 4). Its southern part, represented by schlieren pegmatite, is similar in $\mathrm{K}_{2} \mathrm{O} / \mathrm{Na}_{2} \mathrm{O}$ ratio (Figure 2) and in rare-element composition to the gneisses of the Priolkhonye and pegmatoid leucogranites of the Sharanur complex, which do not exhibit rare-metal specialization. Iliksin, the more northerly occurrence of vein pegmatite, is a typical rare-metal formation with a diverse association of rare minerals. By the nature of mineral paragenesis, this part of the pegmatite body is very similar to the Tashkiney rare-metal pegmatite of the Olkhon island. The similarity mentioned also shows in the enrichment of both pegmatite bodies with rare elements such as $\mathrm{Be}, \mathrm{Cs}, \mathrm{Rb}, \mathrm{Nb}, \mathrm{Ta}$, and at the same time by the presence of deep minima in the concentrations of $\mathrm{Ba}, \mathrm{Sr}, \mathrm{Eu}$, and $\mathrm{Zr}$ (Figure 3). These geochemical features of the Iliksin pegmatite rare-metal rocks are also close to the Tashkiney pegmatite classed as Be-Nb-Ta mineralogical-geochemical type. Along with that, FLi-Ta mineralization (Li mica, fluorite, tantalite, columbite), as well as a sharp enrichment of rocks with these rare elements, characteristic of granites and pegmatites of the $\mathrm{Li}-\mathrm{F}$ mineralogical-geochemical type, were discovered in this northern vein part of the Iliksin pegmatite. 
The U-Pb isotope LA-ICP-MS method [13] was used by V.B. Khubanov (GIN SB RAS, Ulan-Ude) to date zircons isolated from pegmatoid rocks of different parts of the Iliksin vein. For zircon from the southern part graphic pegmatite of the vein, an average date value of $458.3 \pm 1.4 \mathrm{Ma}$ was obtained (Figure 5a), which basically coincides with the age of the Sharanur complex granites of the Central Dome Zone of the Priolkhonye region. Consequently, the southern part of the Iliksin pegmatite was formed in a close age interval with the Sharanur pegmatoid granites, to which it is similar in composition and geochemical characteristics. For zircon from the rare-metal pegmatite of the vein northern part (Figure 5b), an average age of 431.3 $\pm 3.7 \mathrm{Ma}$ was obtained, which indicates the formation of this vein part with rare-metal mineralization at a later post-collisional stage of its origin in a tectonic setting with the formation of submeridional fault zones in the Olkhon region.

4.3 Rare-metal pegmatites with amazonite of Li-F mineral-geochemical type (Priolkhonye) Aya pegmatites. Rare-metal pegmatites with amazonite occur within the Aya massive on the lake Baikal shore (Aya Bay) in Priolkhonye. The massive takes up an area of about $2 \mathrm{~km}^{2}$ and is composed of rocks of 3 intrusive phases: from coarse-grained biotite granites to medium-finegrained leucogranites and the final phase of vein granites and pegmatites. The Aya intrusion is confined to a large fault structure of the north-eastern strike, and the age of its granites was previously estimated by the U-Pb dating (by the SHRIMP-II method) and equalled $468 \pm 6 \mathrm{Ma}$ [19] and $469 \pm 1.5 \mathrm{Ma}$ [20], which is agrees well with the age range of early Paleozoic granitoids of the Sharanur complex. The formation of autochthonous (Sharanur complex) and intrusive (multiphase Aya massive) granitoids corresponds to collisional events in the Olkhon metamorphic terrain, and the formation of syncollisional granitoids is associated with both the processes of melting of the crustal protolith and magmatic differentiation [21].

At the initial stage of investigations in the Aya massive vein series, two types of pegmatites were distinguished by the vein morphology, the nature of contacts, and the degree of differentiation [22]. The first type includes lense-like or schlieren-like bodies with no longer than 5-7 m, of an unevenly grained usually apographic structure, weakly differentiated with a medium-grained endocontact edging of granite quartz-microcline composition. Veins of the second type are characterized by a complex morphology and a length of up to 30-40 m with vein bodies thickness of 3-4 m. They are expressed by a greater differentiation and diversity of mineral composition. In addition to white microcline, these veins often contain amazonite in association with oligoclase (No. 25-30) and albite (No. 4-11), which predominate in the endocontact zones of the veins, and in their central parts the role of microcline increases, where amazonite crystals up to $10-15 \mathrm{~cm}$ in size are found in nests with a large-block structure. Along with feldspar and quartz, these rare-metal pegmatites contain agglomerates of zinnwaldite flakes, sometimes in accretions with tourmaline, and garnet (up to $86 \mathrm{~mol} \%$ of spessartin minal), magnetite, less often - muscovite and fluorite [23]. Studies by V.B. Savelyeva and co-authors (2013) found in the block amazonite Aya pegmatite Ta mineralization represented by microlith, plumb-microlith and minerals of the columbite-tantalite group. Elevated Ta concentrations are also observed in a number of other minerals (fergusonite, samarskite, wolframite) from amazonite pegmatite, which also contains ixiolite, cassiterite, and zircon. Minerals that concentrate rare earths and $\mathrm{Y}$ in pegmatite are represented by fluorite, monazite, xenotime, and fluorocarbonates. On the basis of the published and new data, it can be suggested that late amazonitic pegmatite veins cutting the Aya granite massive are characterized by a considerable diversity of accessory minerals, which allows some authors to class them as rare-metal-rare-earth formations with complex mineralization [23]. At the same time, it should be stressed that the Aya amazonite pegmatites differ in their petrogeochemical features from the rare-metal pegmatites of Tashkiney and Iliksin, and belong to the Li-F mineralogical-geochemical type.

According to earlier studies of U-Pb zircon systems of the Priolkhonye and the Olkhon islands, including the Aya massive [24], dates of small bodies of granites and pegmatites were obtained in the range of $410-386 \mathrm{Ma}$. These age values are very close to the results of ${ }^{40} \mathrm{Ar} /{ }^{39} \mathrm{Ar}$ measurements in the spectra of biotites isolated from the pegmatite vein that crosscut the Aya 
granites, where a plateau corresponding to the age values of $412.8 \pm 4.2$ and $391.1 \pm 3.9 \mathrm{Ma}$ is observed. The authors of this work [19] believe that these dates may represent the age of formation of late granite-pegmatites within the Aya intrusion. Using the LA-ICP-MS method [13], V.B. Khubanov (GIN SB RAS, Ulan-Ude) dated zircons from a large pegmatite vein with amazonite in the apical part of the Aya massive to obtain the age value of $453.9 \pm 2.8 \mathrm{Ma}$ (Figure $6 a)$. Based on the studied relationships of rocks, their mineralogical and geochemical characteristics, as well as dates obtained by various methods, it can be concluded that vein pegmatites with amazonite, which crosscut the Aya intrusion, are not associated with the formation of granitoids and pegmatoid rocks of the Sharanur complex and are post-collisional formations.

Ulan-Nur pegmatites. In Priolkhonye, to the east of pegmatite occurrence in the granites of the Aya intrusion, a vein series of amazonite-containing pegmatites of the Ulan-Nur cape was found among magnesian marbles and alkaline rocks of the Tazheran massive. These are steeply falling subparallel vein bodies located with the interval of up to $1 \mathrm{~km}$ with individual veins being up to $25 \mathrm{~m}$ thick [25]. The largest among the Ulan-Nur pegmatite veins is traced along a stretch of 140 $\mathrm{m}$, its zoning nature and a significant differentiation degree make it similar to the Aya rare-metal pegmatite. It is composed of quartz, microcline-pertite, albite-oligoclase, biotite and a distinct fine-grained endocontact zone with oligoclase and titanite. Graphic microcline pegmatite in the central part of the vein is replaced by a block zone with large amazonite crystals, which also contains albite secretions, or a quartz zone. The graphic pegmatite part of the vein was found to contain less frequent hornblende, garnet, tourmaline and magnetite, with muscovite observed along with biotite. A number of researchers identified in a large vein the following accessory minerals: zircon, allanite, titanite, hatchettolite, apatite, rutile, beryl, monazite, bismutin, fluorite and molybdenite. Ulan-Nur rare-metal pegmatite with amazonite was used to establish the influence of host alkaline rocks on its mineral composition with the appearance of a characteristic mineral association in the endocontact zone: pyrochlore, cirtolite, fergusonite, torite and pyromorphite [26]. Early studies discovered the similarity of mineral and chemical composition of amazonite-containing pegmatites in the areas of the Aya massive and the UlanNur cape. Based on the latest results, we emphasize that these rare-metal pegmatites are characterized by the similarity of both mineral associations within them and the rare-element composition (Figure 3), which confirms that the Ulan-Nur and Aya pegmatites belong to the Li-F mineral-geochemical type and differ from the pegmatoid rocks of the early Paleozoic Sharanur complex (Tables 5, 6).

The first data on the age of zircons obtained by V. B. Khubanov (GIN SB RAS) using the LA-ICP-MS method for the amazonite pegmatite Ulan-Nur (443.9 $\pm 2.2 \mathrm{Ma})$ are close to the age of formation of the Aya rare-metal pegmatites of the Olkhon region of Pribaikalye (Figure 6b).

\section{Discussion}

Geochronological and petrological-geochemical studies of granite-pegmatite systems in the southern frame of the Siberian craton (Pribaikalye), found that pegmatite formation processes occurred in different geological age epochs and in changing geodynamic environments. Pegmatoid granites and pegmatites in the Olkhon region were formed both in genetic relation with the development and evolution of autochthonous and intrusive granitoid magmatism, and in the form of vein bodies, which are not obviously related to granitoids. The research suggests distinguishing pegmatoid formations without rare-metal mineralization and their rare-metal types, which differ in mineralogical and geochemical peculiarities. The zoning of the internal structure of Pribaikalye pegmatite bodies is presented, new data of their age are systematized and new information on their age is obtained as compared to different-aged granitoids of complexes, mineralogical and geochemical typification of pegmatoid granites and pegmatites is accomplished along with the analysis of the conditions of their formation peculiarities. 
The Solzan granitoid massive (Khamar-Daban) was previously studied as one of the model objects of collisional magmatism in Pribaikalye. It stretches in the sub-latitude direction for $26 \mathrm{~km}$ with a width of 1.5 to $5 \mathrm{~km}$. The age of $519 \pm 26$ million years was estimated by the $\mathrm{Rb}-\mathrm{Sr}$ method for granitoids of the Solzan massive [27]. U-Pb dating of zircons carried out by the SHRIMP-II method at the VSEGEI Station (St. Petersburg) showed that the Solzan massive formation began at the stage of cover-thrust tectogenesis (519-513 Ma) and ended at the stage of decompression (490-480 mln years). The mechanism of the massive formation is partial melting at high temperatures of the amphibolite facies with a slight movement of partially homogenized melt. Granites of Khamar-Daban (Solzan massive), as well as the Sharanur complex (Priolkhonye) and plagiomigmatites and plagiogranites close to them by material composition are typical syncollisional formations, with their melt source being gneisses and slates of KhamarDaban and Olkhon metamorphic strata [10]. As in the Olkhon region, the migmatites and leucogranites of Khamar-Daban demonstrate developed pegmatites, which are lenticular, schlierlike, or layered bodies of orthoclase-plagioclase biotite pegmatoid rocks with a hypidiomorphicgrained structure. As accessory minerals, they contain biotite, garnet, apatite, graphite, zircon, and sometimes tourmaline [28].

The rocks of the Olkhon region from autochthonous and intrusive granitoids to late pegmatites are peraluminous and usually high in potassium, they have high phosphorus content, but low $-\mathrm{Na}_{2} \mathrm{O}, \mathrm{CaO}, \mathrm{MgO}$ and $\mathrm{FeO}$ contents. This type of rocks of the Sharanur complex tends to the average composition of the continental crust in terms of the content of most elements (Figure 3). Geochemical data confirm that the early Paleozoic granitoids of Pribaikalye have a crustal origin and inherited their composition from the host shale-gneiss strata. Among the Khamar-Daban and Sharanur collisional granitoids, the type of pegmatoid leucogranites and pegmatites is close to them in age and mineral composition. These rocks might have been formed at the stage of completion of magmatic differentiation of the intrusive complexes compared.

At the post-collisional stage of the Olkhon region of geological development, various mineral and geochemical types of rare metal pegmatites were formed, which were previously assigned to the fluoro-tantalum-yttrium and beryllium-rare earth geochemical evolutionary series $[29,22]$. Of importance here is the Tashkiney pegmatite, first identified on the Olkhon island; it belongs to the Be-Nb-Ta mineralogical-geochemical type, which is characterized by high concentrations of not only beryllium, but also $\mathrm{Rb}, \mathrm{Cs}, \mathrm{Nb}, \mathrm{Ta}, \mathrm{Sn}, \mathrm{Pb}$ and by minimal contents of $\mathrm{Li}, \mathrm{F}, \mathrm{B}$ (Figure 3). Characteristic rare metal and rare earth minerals within this pegmatite are beryl, monazite, xenotime, zircon, cassiterite, wolframite and hatchettolite. The Tashkiney pegmatite was formed at the latest age period, when the formation of leucogranites and pegmatites vein bodies is controlled by emergence of submeridional fractures in post-collision environment.

The more complex internal structure of the Iliksin pegmatite in the Priolkhonye region, represented by pegmatoid rocks of different ages, distinguishes it from other rare-metal pegmatites in the region. The distribution pattern of most rare elements on spidergram (Figure 3) rare-metal varieties of the Iliksin and Tashkiney pegmatites obey common regularities, which show in high contents of $\mathrm{Be}, \mathrm{Rb}, \mathrm{Cs}, \mathrm{Nb}, \mathrm{Ta}, \mathrm{Sn}$ and $\mathrm{Pb}$. In the distribution of rare earths, the rocks of both pegmatites are characterized by close concentrations of light lanthanides, a deep Eu minimum, but the Iliksin pegmatite intensely enriched with heavy elements of the REE spectrum. In addition, one of the main specific features of this pegmatite is also its enrichment with lithium with the occurrence of Li micas in Northern Iliksin (protolithionite and lepidolite). Mineralization with the formation of Li mica is characteristic of granites and pegmatites of Li-F type, which are widely spread in Mongolia, Transbaikalye and Pribaikalye (Khamar-Daban) $[30,31]$. In contrast to typical $\mathrm{Li}-\mathrm{F}$ granites and pegmatites in these regions, the rocks of the Iliksin and especially of the Tashkiney vein in Priolkhonye have lower fluorine content in rare metal varieties. This may indicate special conditions of the fluid mode in the course of formation of rare-metal pegmatoid rocks of the Olkhon region at the post-collision stage. In the light of 
recent data [32], it can be assumed that different generations of granite pegmatites are manifested in Pribaikalye of the Baikal region: beryl-bearing with tantalum-hatchettolite and sometimes with muscovite (Tashkiney) associated with the leucogranite complex, and natro-lithium ( $\mathrm{Li}, \mathrm{Ta}$, Cs, Sn, Be) pegmatites (Iliksin).

Among the studied rare-metal pegmatites of the Olkhon region veins bodies with amazonite crosscuting the Aya massive rocks are very similar to $\mathrm{Li}-\mathrm{F}$ type granites and pegmatites veins by the mineralogical and geochemical characteristics. The available literary and new mineralogical and geochemical data suggest the possibility of isolating a special Aya type of pegmatites in Priolkhonye, containing mineralization characteristic of both rare-metal granitepegmatite systems (F-Li-Ta-Rb-Cs-Sn-W) and rare-earth pegmatites (Be, Nb, Y, HREE, Zr, F). The comparative geochemical characteristics of amazonite Aya pegmatites and Ulan-Nur vein bodies clearly show the similarity in the distribution of rare elements manifested in the enrichment of rare metal rocks $\mathrm{Rb}, \mathrm{Cs}, \mathrm{Be}, \mathrm{Ta}, \mathrm{Sn}, \mathrm{Pb}$, Th, and $\mathrm{U}$ at minimal concentrations (in relation to the composition of upper continental crust) of $\mathrm{Ba}, \mathrm{Sr}, \mathrm{La}, \mathrm{Ce}, \mathrm{Nd}, \mathrm{Eu}$, and $\mathrm{Zr}$. This might suggest probable genetic relationship of Priolkhonye amazonite-bearing pegmatites, as well as their inclusion to the same mineralogical-geochemical type, which is closest to the composition of Li-F granites dating back to the post-collisional magmatism in the Olkhon region.

Thus, pegmatoid granites and pegmatites of various ages (458-390 Ma) are manifested here, the formation of which occurred both at the collision and post-collision stages of the geological development of Pribaikalye. Pegmatoid granites and pegmatites studied in the Olkhon region and containing concentrated rare-metal mineralization are more widely developed in the regions of Transbaikalye, Pribaikalye and Mongolia and belong to the characteristic manifestations of Phanerozoic intra-plate magmatism. In practical terms, concentrated rare-metal mineralization may have a genetic relation with the development of $\mathrm{Be}-\mathrm{Nb}-\mathrm{Ta}$ and $\mathrm{Li}-\mathrm{F}$ pegmatites, which require additional and complex isotope-geochemical studies.

\section{Conclusions}

1. In the Olkhon region of Pribaikalye, pegmatoid granites and pegmatites were built up within a wide age range (458-390 Ma), they form morphologically diverse (schlieren-shaped, lens and vein) bodies occupying different geological and structural positions, and are represented by different mineralogical and geochemical types.

2. Pegmatoid rocks among the early Paleozoic autochthonous and allochthonous granitoids of the Sharanur complex are similar in petrochemical characteristics to the Sharanur granites and belong to the series of normal alkalinity with $\mathrm{K}_{2} \mathrm{O} \geq \mathrm{Na}_{2} \mathrm{O}$. Being products of the evolution of early Paleozoic collisional magmatism, pegmatoid granites and pegmatites are geochemically similar to granites in the nature of rare and rare earth elements distribution spectra.

3. Middle Paleozoic pegmatite vein bodies in the Olkhon region (Tashkiney, Iliksin, Aya, UlanNur) controlled by crack submeridional fracture zones, in contrast to the early Paleozoic pegmatoid formations, belong to the formation of rare metal pegmatites [28], since they contain various rare-metal mineralization, and are characterized by geochemical differences between rocks and minerals and represented by several mineralogical-geochemical types.

4. The Iliksin pegmatite (Priolkhonye) has the most complex internal structure and is represented by pegmatoid formations of different ages. The significant similarity of the northern part of the vein with the rare-metal Tashkiney pegmatite (the Olkhon Island) shows in the enrichment of both pegmatite bodies with such rare elements as $\mathrm{Be}, \mathrm{Cs}, \mathrm{Rb}, \mathrm{Nb}$, Ta, and $\mathrm{Sn}$. In the REE distribution in the rocks of both pegmatites, the similarity is manifested in the close content of light lanthanides, a deep $\mathrm{Eu}$ minimum, however, the Iliksin pegmatite Iliksin is intensely enriched with heavy elements of REE spectrum. According to these geochemical features, the rare-metal rocks of the Iliksin and Tashkiney pegmatites can be referred to the $\mathrm{Be}-\mathrm{Rb}-\mathrm{Nb}-\mathrm{Ta}$ mineralogical-geochemical type. 
5. Among the studied rare-metal pegmatites of the Olkhon region, vein bodies with amazonite occur; their mineralogical and geochemical characteristics are closest to the rare-metal Li-F granites previously found in Mongolia and Transbaikalye [29]. Amazonite pegmatites in the Priolkhonye do not show any relation to the evolution of the Aya granite-leucogranite massive of the Sharanur complex and contain mineralization characteristic of both rare-metal granitepegmatite systems (F-Li-Ta-Cs-Sn-W) and rare-earth pegmatites (Be, Nb, Y, HREE, Zr, F). Age and geochemical affinity of the Ulan-Nur and Aya amazonite pegmatites is established, which suggests the genetic relationship of Priolkhonye rare-metal pegmatites and their assignment to a common mineralogical-geochemical type of post-collisional magmatism in the Olkhon region.

Author Contributions: Conceptualization, V.A. and N.Sh.; methodology, V.A., L.K., V.M. and N.Sh.; validation, V.A., L.K. and N.Sh ; data curation, N.Sh and L.K.; original draft preparation, V. A.; writing - review and editing V.A., L.K. and N.Sh.;, All authors have read and agreed to the published version of the manuscript.

Funding: The study was carried out as part of a government assignment (topic ID 0350-20190007) and was supported by grants 19-05-00172 and 20-55-44002-Mong_a from the Russian Foundation for Basic Research.

Acknowledgments: We wish to thank V.B. Khubanov (Institute of Geology SB RAS, Ulan-Ude) for aid in the manuscript preparation. The authors are very grateful to the anonymous reviewers for the great work of reviewing the article and the valuable comments and suggestions that contributed to a significant improvement in the manuscript.

Conflicts of Interest: The authors declare no conflict of interest.

\section{References}

1. Fedorovsky, V.S.; Vladimirov, A.G.; Khain, E.V.; Kargopolov, S.A.; Gibsher, A.S.; Izokh, A.E. Tectonics, metamorphism and magmatism of collision zones of Central Asian Caledonides. Geotektonika.1995, 3, 3-22.

2. Yarmolyuk, V.V.; Kovalenko, V.I.; Kuzmin, M.I. North-Asian activity superplume in the Phanerozoic: magmatism and geodynamics. Geotektonika. 2000, 5, 3-29.

3. Gladkochub, D.P.; Donskaya, T.V.; Fedorovsky, V.S.; Mazukabzov, A.M.; Larionov, A.N.; Sergeev, S.A. The Olkhon metamorphic terrane in the Baikal region: An Early Paleozoic collage of Neoproterozoic active margin fragments. Russ. Geol. Geophys. 2010, 51 (5), 447-460 (571588).

4. Distanova, A.N. Granitoid magmatism of Early Paleozoic orogens. Russ. Geol. Geophys. 2013, 54 (6), 606-612 (787-796).

5. Donskaya, T.V.; Gladkochub D.P.; Fedorovsky V.S.; Mazukabzov A.M.; Cho, M.; Cheong, W.; Kim, J. Synmetamorphic granitoids ( 490 Ma) as accretion indicators in the evolution of the Ol'khon terrane (western Cisbaikalia). Russ. Geol. Geophys. 2013, 54 (10), 1205-1218 (15431561).

6. Makrygina, V.A.; Antipin, V.S. Petrology and Geochemistry of Metamorphic and Igneous Rocks of the Olkhon Region; GEO Novosibirsk, 2018; 248 p, doi:10/21782/B978-5-9909584-49. (in Russian).

7. Eskin, A.S.; Ez, V.V.; Grabkin, O.V.; Letnikov, F.A. Correlation of the Endogenic processes in metamorphic complexes of Baikal area; Novosibirsk, Nauka, 1979; 117 p.

8. Fedorovsky, V.S. Geologic Map of Southwestern Part, Olkhon Area; Scale 1:100000 GIN RAS: Moscow, Russia, 2004.

9. Makrygina, V.A.; Antipin, V.S.; Lepekhina, E.N.; Tolmacheva, E.V.; Gorlacheva, N.V. Genetic peculiarities and the first data on the $\mathrm{U}-\mathrm{Pb}$ age of the Solzan granitoid massif, KhamarDaban (Baikal area). Dokl. Earth Sci. 2013, 449 (1), 335-341.

10. Antipin, V.S.; Gorlacheva, N.V.; Makrygina, V.A. Geochemistry of Early Paleozoic granitoids of the Baikal region and their geodynamic setting exemplified by the Khamar-Daban 
Ridge and Olkhon Island. Russ. Geol. Geophys. 2014, 55 (2), 228-243 (177-189), doi: 10.1016/j.rgg.2014.01.005.

11. Sheptyakova, N.V.; Antipin, V.S.; Kushch, L.V. Paleozoic collisional and intraplate granitoids of the Baikal area: comparative geochemistry and petrogenesis. Russ. Geol. Geophys. 2016, 57 (7), 1027-1039 (1307-1322), doi: 10.15372/GiG20160703.

12. Geostandards Newletter. 1994. Vol. 18. Spec. Issue, July.

13. Khubanov, V.B.; Buyantuev, M.D.; Tsygankov, A.A. U-Pb dating of zircons from $\mathrm{PZ}_{3}-\mathrm{MZ}$ igneous complexes of Transbaikalia by sector-field mass spectrometry with laser sampling: technique and comperison with SHRIMP. Russ. Geol. Geophys. 2016, 57 (1), 241-258, doi: 10.15372/GiG20160113.

14. Vladimirov, A.G.; Volkova, N.I.; Mekhonoshin, A.S.; Travin, A.V.; Vladimirov, V.G.; Khromykh, S.V.; Yudin, D.S.; Kolotilina, T.B. The geodynamic model of formation of Early Caledonides in the Olkhon Region (West Pribaikalie). Dokl. Earth Sci. 2011, 436 (2), 203-209.

15. Mikheev, E.I.; Vladimirov, A.G.; Fedorovsky, V.S.; Bayanova, T.B.; Mazukabzov, A.M.; Travin, A.V.; Volkova, N.I.; Khromykh, S.V.; Khlestov, V.V.; Tishin, P.A. Age of overthrusttype complexgranites in accretionary-collisional system of the early Caledonides (western Baikal region). Dokl. Earth Sci. 2017, 472 (2), 152-158, doi: 10.7868/S0869565217050206.

16. Rudnick, R.L.; Gao, S. Composition of the Continental Crust. In: Holland H.D, Turekian KK (eds). Treatise on Geochemistry. Elsevier-Pergamon, Oxford. 2003, 3, 1-64, doi: 10.1016 / B008-043751-6/ 03016-4.

17. Makrygina, V.A.; Suvorova, 1.F.; Antipin, V.S.; Makagon, V.M. Rare-metal pegmatoid granites, markes of the beginning of the Hercynian within-plate stage in the Olkhon region of the Baikal area. Russ. Geol. Geophys. 2018, 59 (12), 1626-1639, doi: 10.15372/GiG20181208.

18. Makagon, V.M.; Belozerova, O.Yu. Bismutotantalite from pegmatites of the Western Baikal Region, East Siberia, Russia. PEG, Abstracts. New Hampshire, USA. 2013, 88-89.

19. Yudin, D.S., Khromykh, S.V., Mekhonoshin, A.S., Vladimirov, A.G., Travin, A.V., Kolotilina, T.B., Volkova, M.G. ${ }^{40} \mathrm{Ar} /{ }^{39} \mathrm{Ar}$ age and geochemical features of syncollisional gabbroids and granites from the Western Baikal Region: evidence from the Birkhin massif and its folded framing. Dokl. Earth Sci. 2005, 405 (2), 1261-1265.

20. Vladimirov, A.G.; Khromykh, S.V.; Mekhonoshin, A.S.; Volkova, N.I.; Travin, A.V.; Yudin, D.S.; Kruk, N.N. U-Pb dating and Sm-Nd systematics of igneous rocks in the Olkhon region (Western Baikal Coast). Dokl. Earth Sci. 2008, 423 (2), 1372-1375, doi: 10.1134/S1028334X08090092

21. Antipin, V.S.; Kushch, L.V.; Sheptyakova, N.V.; Vladimirov, A.G. Geochemical evolution of the early Paleozoic collisional magmatism from autochthonous migmatites and granitoids to multiphase granite intrusions (Sharanur and Aya complexes, Baikal Region). Russ. Geol. Geophys. 2018, 59, 1616-1625, doi: 10.15372/GiG20181207.

22. Shmakin, B.M.; Zagorsky, V.E.; Makagon V.M. Granitic pegmatites. Rare-Earth Pegmatites. Pegmatites of Unusual Composition; Nauka, Novosibirsk, 2007; 4, 432 p. (in Russian).

23. Savelyeva, V.B.; Kanakin, S.V.; Karmanov, N.S. New data on mineralogy of amazonite pegmatites in Priolkhonye (Western Baikal Region). Zapisky RMO. 2013, Pt CXLII, 2, 44-66.

24. Letnikov, F.A.; Khalilov, V.A.; Savelyeva, V.B. Isotope dating of the endogenic processes in Pryolkhonie. Dokl. Earth Sci. 1995, 344 (1), 96-100.

25. Shmakin, B.M.; Makagon, V.M.; Koneva, A.A.; Ivanov, A.N. Amazonite pegmatites of the Olkhon Region (Western Baikal area). Zapisky RMO.1973, 103, 5, 591-599.

26. Sklyarov, E.V.; Fedorovsky, V.S.; Kotov, A.B.; Lavrenchuk, A.V.; Mazukabzov, A.M.; Levitsky, V.I.; Sal'nikova, E.B.; Starikova, A.E.; Yakovleva, S.Z.; Anisimova, I.V.; Fedoseenko, A.M. Carbonatites in collisional settings and pseudo-carbonatites of the Early Paleozoic Olkhon collisional system. Russ. Geol. Geophys. 2009, 50 (12), 1091-1106 (1405-1423). 
27. Makrygina, V.A.; Sandimirova, G.P.; Nikolaev, V.M.; Plyusnin, G.S. The Rb - Sr age of metamorphic rocks of the Khamar-Daban complex (southwestern Baikal area). Isotope Dating of Metamorphism and Metasomatism Processes. 1987, Nauka, Moscow, 184-195. (in Russian).

28. Makrygina V.A. Geochemistry of Medium- and Low-Pressure Regional Metamorphism and Ultrametamorphism; Nauka, Moscow, 1981; 200 p. (in Russian)

29. Zagorsky, V.E.; Makagon, V.M.; Shmakin, B.M. Systematics of the granite pegmatites. Russ. Geol. Geophys. 2003, 44 (5), 422-435, doi: 10.31241/FNS.2018.15.064.

30. Kovalenko, V.I. Petrology and Geochemistry of rare-metal granitoids; Nauka, Novosibirsk, 1977; 206 p.

31. Antipin, V.S.; Perepelov, A.B. Late Paleozoic rare-metal granitoid magmatism of the Southern Baikal region. Petrology. 2011, 19 (4), 370-381.

32. Beskin, S.M.; Marin, Yu.B. Pecularites of granite sistems including rare-metal pegmatites. Zapiski RMO. 2019, Pt CXLVIII, 4, 1 - 16, doi: 10.31857/S0869605520060039. 